\title{
Hemoglobin Type Analysis of Ryukyu and Tokara Native Horses
}

\author{
Yukinori Eguchi, Yasutsugu Nakashima, Minoru Oshiro, \\ Masao Sugamata, Hiroshi Takei, Koichi Yanagida* \\ and T'sutomu HASHIGUCHI ** \\ Faculty of Medicine, University of the Ryukyus, \\ Nishihara-cho, Okinawa-ken 903-01 \\ * Iriki Livestock Farm, Faculty of Agriculture, Kagoshima \\ University, Iriki-cho, Kagoshima-ken 895-14 \\ ${ }^{* *}$ Faculty of Agriculture, Kagoshima University, \\ Kagoshima-shi 890
}

(Received June 11, 1990)

\begin{abstract}
Key words: Yonaguni horses, Miyako horses, Tokara horses, hemoglobin types, isoelectric focusing
\end{abstract}

Hemoglobin phenotypes in horses were first classified by BRAEND ${ }^{1)}$ into three groups, in which the fast component/slow component ratios were approximately $60 / 40,80 / 20$ and $100 / 0$, respectively. KILMARTIN and CLEGG ${ }^{5)}$ identified amino acid variation in both tyrosine and phenylalanine at position 24 and glutamine and lysine at position 60 of the equine $\alpha$ globins which were encoded by two closely linked $\alpha$ genes. CLEGG ${ }^{3 j}$ suggested thrce haplotypes; BI, BII and A. Later much rarer haplotypes AII, $N$ and $C$ were also reported ${ }^{2-4}$ ? Recently YoKohama and Mogr ${ }^{7)}$ and YokoHAMA et al. ${ }^{8)}$ reported hemoglobin types in Japanese native horses and noted three haplotypes, BI, BII and A. This paper describes the quantitative analysis of the hemoglobin types of native horses in the Ryukyu Islands (Miyako horses and Yonaguni horses) and of the Iriki group of Tokara horses.

\section{Materials and Methods}

Blood samples were collected from 9 Miyako horses, 8 Yonaguni horses and 19 Tokara horses at the Iriki Livestock Farm of the Kagoshima University. Hemolysates were prepared in the standard manner, and $\mathrm{KCN}$ and ( $p$-Amidinophenyl) Methanesulfonyl Fluoride $\mathrm{HCl}$ were added to the hemoglobin solution. Isoelectric focusing (IEF) was carried out on a $5 \%$ polyacrylamide gel containing glycerol (13\%) and pH 6-8 Pharmalyte (5\%) and pH 3-10 Pharmalyte $(1.25 \%)$ solutions. $0.02 \mathrm{M} \mathrm{NaOH}$ and $0.01 \mathrm{M} \mathrm{H}_{3} \mathrm{PO}_{4}$ were used as a catholyte and an anolyte, respectively. A typical electrophoresis was performed for 3 hours (initially $200 \mathrm{~V}$. $25 \mathrm{~mA} .5 \mathrm{~W}$, and finally $720 \mathrm{~V}, 7 \mathrm{~mA} .5 \mathrm{~W}$ ). After IEF, a gel was fixed in $10 \%$ trichloroacetic acid. The density of the hemoglobin bands was measured using a Biomed soft laser

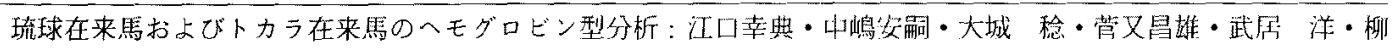

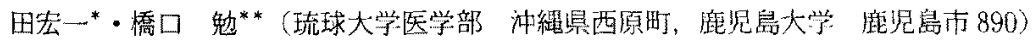

Anim. Sci. Technol. (Jpn.) 62 (4): 351-353 351 
Eguchi, Nakashima, Oshiro, Sugamata, Takei, Yanagida and Hashiguchi

Table 1. Mean peak height ratio and distribution of the hemoglobin types identified in the Ryukyu and Tokara native horses following isoelectric focusing

\begin{tabular}{|c|c|c|c|c|c|c|c|}
\hline \multirow[t]{2}{*}{$\begin{array}{l}\text { Hemoglobin } \\
\text { type }\end{array}$} & \multicolumn{4}{|c|}{$\begin{array}{c}\text { Mean peak height ratio } \\
\text { Band position }\end{array}$} & \multicolumn{3}{|c|}{ Frequency distrubution } \\
\hline & 1 & 2 & 3 & 4 & $\begin{array}{l}\text { Miyako } \\
\text { horses }\end{array}$ & $\begin{array}{l}\text { Yonaguni } \\
\text { horses }\end{array}$ & $\begin{array}{l}\text { Tokara } \\
\text { horses }\end{array}$ \\
\hline $\mathrm{BI} / \mathrm{BI}$ & & 60.2 & & 39.8 & 3 & 0 & 0 \\
\hline $\mathrm{BI} / \mathrm{BII}$ & 30.8 & 34.2 & 17.0 & 18.0 & 3 & 3 & 0 \\
\hline $\mathrm{BII} / \mathrm{BII}$ & 59.0 & & 41.0 & & 2 & 4 & 6 \\
\hline $\mathrm{A} / \mathrm{A}$ & & 100.0 & & & 0 & 0 & 9 \\
\hline $\mathrm{A} / \mathrm{BII}$ & 35.9 & 47.1 & 17.0 & & 0 & 1 & 4 \\
\hline \multirow[t]{2}{*}{$\mathrm{AII} / \mathrm{BI}$} & 47.4 & 33.7 & & 18.9 & 1 & 0 & 0 \\
\hline & & & & Total & 9 & 8 & 19 \\
\hline
\end{tabular}

Band position is numbered from the most acidic band

densitometer (model SLR-TRER).

\section{Results and Discussion}

Table 1 presents the mean value for the peak height ratio of hemoglobin components in various hemoglobin types and distribution of the hemoglobin types in the three groups of horses. The haplotype frequencies calculated from the present data are BI 0.56 , BII 0.39 and AII 0.06 in Miyako horses and BI 0.19 , BII 0.75 and $\mathrm{A} 0.06$ in Yonaguni horses. YoKoнamA et $a l^{8)}$ reported the frequencies of haplotypes in 13 Yonaguni horses as BI 0.462, BII 0.500 and A 0.038 . The numbers of samples examined by both YOKOHAMA et al. ${ }^{8)}$ and us represent a small portion of the Yonaguni horse population. Hemoglobin type analysis on a substantial number of Yonaguni native horses is therefore needed. A rare hemoglobin type, AII/BI, was found in the Miyako horses. The peak height ratio of hemoglobin components in this type was similar to that of AII/BI type reported by PAtTerson and BeLL ${ }^{6}$. However, the AII haplotype was not detected by YoxoHama et al. ${ }^{8}$ ' who examined 250 Japanese native horses from seven different breeds. We found that the haplotype frequencies in 19 Tokara horses were A 0.58 and BII 0.42 . Similar results were reported by YokoнAMA et $a l^{8)}$ on 15 Tokara native horses. All the
Tokara horses we analysed in this study have been raised at the Iriki Livestock Farm of Kagoshima University. Two other clusters of Tokara horses are known, one in Nakanoshima and another in Mt. Kaimon Natural Park of Kagoshima prefecture. It will be of interest to examine the hemoglobin type distribution among these horses.

\section{Acknowledgment}

The authors wish to thank Mr. S. Y AMAZATO, Secretary-general of Miyako Shi-Cho-Son Association, Mr. M. Shimabukuro, Curator of Nago City Museum and Mr. K. Maefusato, Advisor of the Chief of the Building Section of Yonaguni Town Office, for supplying them with horse blood samples.

\section{References}

1) Braend, M., Genetic variation of horse hemoglobin. Hereditaria, 58 : 385-392. 1967.

2) Braend, M., Clegg, J.B. and Storset, A., Inheritance of an abnormal haemoglobin haplotype in horses and its possible influence on blood values. Acta Vet. Scand., 24: 384-391. 1983.

3) ClegG, J.B., Horse haemoglobin polymorphism. Ann. N. Y. Acad. Sci., 241: 61-69. 1970.

4) Hosseinion, M. and ClegG, J.B., A horse with an unusual haemoglobin phenotype. Proc. R. Soc. Lond., B 176 : 245-246. 1970. 


\section{Hemoglobin Types of Native Horses}

5) Kilmartin, J.V. and ClegG, J.B., Aminoacid replacements in horse haemoglobin. Nature, 213 : 269-271. 1967.

6) Patterson, S.D. and Beli, K., Quantitative analyses of haemoglobin types in Australian horses. Anim. Blood Groups Biochem. Genet., 16 : 239-242. 1985.

7) Yokohama, M. and Mogi, K., Polymor- phism of equine hemoglobin by the isoelectric focusing method. Jpn. J. Zootech. Sci., 54: 794-797. 1983.

8) Yokohama, M., Watanabe, $Y$. and Mogi, $\mathrm{K}$., On the hemoglobin types of Japanese native horses. Jpn. J. Zootech. Sci., 56: 624-627. 1985. 